\title{
Control Effect of Palmitoyl Teterapeptide-7 Gel to Inflammatory Responses Elicited by PM10
}

\author{
Min-Kyeong Kim ${ }^{1}$, Min-Jung Kim², Ju-Weon $\mathrm{Kim}^{1}$, Jeong-Hee Kim² \\ ${ }^{1}$ Department of Beauty Design, Graduate School of Wonkwang University, Iksan-si, Jeollabuk-do, Korea \\ ${ }^{2}$ Division of Beauty Design, College of Natural Science, Wonkwang University, Iksan-si, Jeollabuk-do, Korea
}

\author{
"Corresponding author: Jeong-Hee Kim, \\ Division of Beauty Design, College of \\ Natural Science Wonkwang University, 460 \\ Iksan-daero, Iksan-si, Jeollabuk-do 54538, \\ Korea \\ Tel.: +82635806898 \\ Fax: +82638507301 \\ Email: jh@wku.ac.kr
}

Min-Kyeong Kim and Min-Jung Kim contributed equally to this work.

\section{Received February 28, 2021}

Revised April 17, 2021

Accepted April 21, 2021

Published June 30, 2021

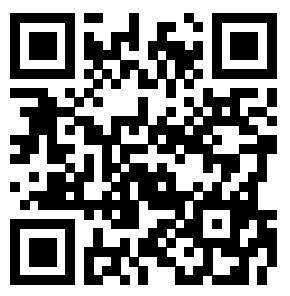

\begin{abstract}
Purpose: As a cosmetic approach to prevent pollution-induced skin damage, the topical application of skincare products, infused with functional ingredients, can offer an optimal solution to skin problems. The study aims to assess the anti-inflammatory effect of PT-7 gel. Methods: This study prepared antipollution cosmetics using palmitoyl tetrapeptide-7 (PT-7; 3\% PT-7 gel, 5\% PT-7 gel) and performed safety testing. For the safety assessment, the human repeat insult patch test (HRIPT) was performed to detect erythema occurrence on the patch area, following the ICDRG criteria. The panels comprised of 30 adults, aged 20-50 years. Furthermore, this study also analyzed particulate matter (PM) 10-induced inflammation on the skin of a hairless mouse by immunohistochemistry and Western blot. Results: The cosmetic safety testing results showed no skin reactions to antipollution gels containing PT7. Immunohistochemistry and the Western blot analysis demonstrated reduced levels of IL-1 $\beta$ and IL- 6 expression levels in the 3\% PT-7 and 5\% PT-7 application groups after PM10 treatment. In particular, after PM10 treatment, the IL-1 $\beta$ and IL- 6 expression levels were statistically significantly decreased in the group treated with 5\% PT-7. Conclusions: Collectedly, this study provided evidence of the PT-7 gel's safety and found that PT-7 gel reduced the IL-1 13 and IL- 6 expression levels caused by PM10 exposure. In view of these results, it supports that PT-7 is a promising antipollution cosmetic ingredient with great commercial potential.
\end{abstract}

Keywords: Anti-pollution, Palmitoyl tetrapeptide-7, Particulate matter, Antiinflammation, Cosmetic

\section{Introduction}

미세먼지는 민감성 피부에 피부염, 자극, 소양감을 유발시킬 수 있으며, 건강한 피부도 유해물질에 지속적으로 노출되면 민감성 피 부로 변화할 가능성이 있다(Krutman et al., 2014). 또한 미세먼지 는 인체 유래 각질형성세포와 피부섬유아세포에서 세포사멸의 요인 으로 작용하며(An \& Kim, 2019) 생쥐피부에서 $\mathrm{IL}-1 \beta, \mathrm{LL}-6, \mathrm{IL}-8$ 등과 같은 염증성 사이토카인 발현 증가 및 $\mathrm{LL}-6, \mathrm{IL}-8$ 의 단백질 발 현을 증가시킨다는 보고가 있다(Fermández et al., 2018; Park et al, , 2018; Piao et al., 2018). 이 외 연구에서 피부가 미세먼지에 노 출되면 염증 반응을 일으키고 피부 장벽에 손상을 주어 아토피성 피 부염, 여드름, 색소침착, 건선 등의 피부질환 발생이 증가한다는 사
실을 보고하고 있다(Huss-Marp et al., 2006; Kim et al., 2016; Ahn, 2014; Kim et al., 2013). 결론적으로 미세먼지는 손상된 피부 장벽을 통해 피부 내로 침투하여 알레르기 반응, 염증 발생, 색소침 착 및 피부 노화를 직접 유발한다(Araviiskaia et al., 2019; Drakaki et al., 2014; Vierkötter et al., 2010).

현재 출시되고 있는 항오염 화장품은 미세먼지 차단 효과를 중심 으로 한 제품이 주를 이루고 있다. 2018년 식품의약품안전처의 미세 먼지 차단, 세정효과와 관련된 제품 조사 결과 다수의 제품이 효능에 대한 실증자료가 미비하여 실제 고시된 효과가 있는지는 의심스러운 상황이다. 항오염 화장품은 유해환경으로부터 피부를 보호하는 제품 으로, 피부에서 미세먼지 입자를 차단하거나 이미 침투한 미세먼지 를 정화해주는 개념의 화장품을 말한다(Juliano \& Magrini, 2018; 
Lee, 2018). 따라서 현재 출시되고 있는 제품들은 미세먼지에 의한 염증 반응이나 피부 노화에 대한 직접적 효능이 미흡하며, 이러한 한 계점을 해결하기 위해 미세먼지 차단뿐 아니라 미세먼지로 인한 피 부 손상을 방지할 수 있는 항염증 성분을 함유한 제품의 개발이 필요 하다.

펩타이드는 인체에서 독성을 일으킬 가능성이 상대적으로 적 고, 체내에 축적되는 양이 적기 때문에 높은 안전성을 기대할 수 있 어 최근 다양한 분야에서 새로운 활용 소재로 주목받고 있다(Kim et al., 2018; Fields et al., 2008). 특히 화장품 소재로서의 펩타이 드는 분자량이 작고 아미노산 연결고리를 가지고 있어 피부에 유사 한 구조로 피부흡수율이 우수하므로 효용 가치가 높다. 그 중에서도 palmitoyl tetrapeptide-7 (PT-7)은 염증성 사이토카인 $\mathbb{L}-6$ 의 분 비를 감소시키며, 세포외 기질 구조를 강화하고 장기적 사용 시 얼 굴 주름을 감소시키는 것으로 알려져 있다(Mondon et al., 2015; Wilbur \& Bart, 2020). 또한 진피의 콜라겐 섬유 재생 효과와 피부 히알루론산의 양을 증가시켜 피부의 눈에 보이는 주름 및 탄력, 질감 을 개선하므로 주로 안티에이징 제품에 사용하고 있다(Johnson \& Heldreth, 2012).

현재까지 미세먼지에 의한 피부 손상에 관한 선행연구는 다수가 보고되었지만, 미세먼지에 의해 손상된 피부 회복에 대한 기능성 성 분의 발굴 및 in vivo 적용 연구는 미비한 실정이다. 따라서 이 연구 에서는 미세먼지 차단뿐 아니라 미세먼지 노출에 의해 유도된 피부 손상을 회복시킬 수 있는 항오염 화장품의 소재로 PT-7을 선정하여 gel 제형의 화장품을 제조하였다. 제조한 화장품에 대한 제형 안정성 과 피부적용에 대한 안전성을 평가하였으며, PM10 노출에 의해 유 도된 염증을 억제하는 항염증 효능을 평가하기 위해 in vivo에 적용 하여 항염증 효능 평가를 시행하였다.

\section{Methods}

\section{Material}

PM10은 미국국립표준연구소(National Institute of Standard and Technology)에서 승인한 미세먼지 표준물질(Urban dust, Sigma Aldrich, USA)을 구입하였고(Table 1), 실험에 사용하기 위 해 PM10을 propylene glycol에 녹여 $50 \mu \mathrm{g} / \mathrm{mL}$ 농도로 만들었다.

화장품 제조에 사용된 PT-7 은 Peptron (Korea)에서 주문 합성

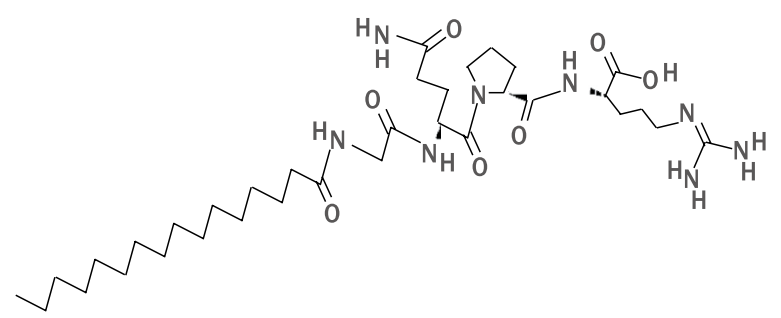

Figure 1. Chemical formula of palmitoyl tetrapeptide-7.

하였다. PT-7은 4 개의 아미노산 사슬을 결합한 형태의 합성 펩타이 드이다(Figure 1).

\section{Preparation}

PT-7 화장품의 제조는 효능 성분의 흡수성이 우수한 gel 제형으 로 제조하였다. PT-7의 효능을 평가하기 위해 정제수와 점증제, 산 화방지제, 방부제 등 최소한의 화장품 원료를 사용하여 제조하였 다. 화장품의 제조에 사용된 원료와 기준량은 Table 2 와 같다. Gel 의 전체 조성은 $100 \mathrm{~g}$ 을 기준으로 정제수 및 점증제, 보습제에 해당 하는 $\mathrm{A}$ 원료를 계량하여 $50^{\circ} \mathrm{C}$ 에서 Agi mixer (Hei-TORQUE value 100; Heidolph Instruments GmbH \& CO., Germany), 800 rpm, $30 \mathrm{~min}$ 조건으로 혼합하였다. B상은 용제 및 산화방지제, 방부제에 해당하는 원료를 계량하여 $50^{\circ} \mathrm{C}$ 에서 Agi mixer, $800 \mathrm{rpm}, 30 \mathrm{~min}$ 조건으로 혼합하였다. $3 \% \mathrm{PT}-7$ gel은 A상의 원료조성에서 정제수 를 $89.47 \mathrm{~g}$ 으로 하고, 항오염 효능 원료인 PT-7을 $3.00 \mathrm{~g}$ 추가하여 제조하였다. $5 \% \mathrm{PT}-7$ gel은 A상의 원료조성에서 정제수를 $87.47 \mathrm{~g}$ 으로 하고, PT-7 $5.00 \mathrm{~g}$ 을 첨가하여 제조하였다.

\section{Human repeated insert patch test}

연구 지원자는 피부질환 및 피부 과민 반응이 없는 건강한 피부를 가진 20-50대 성인 30명을 선정하였다. 연구의 수행을 위해 원광대 학교 생명윤리위원회의 심사를 거쳐 연구수행의 승인을 허가 받았다 (WKIRB-202009-HR-057). IRB 승인 후 연구 지원자를 대상으로 연구의 목적과 과정을 충분히 설명하고 제조한 항오염 화장품의 피 부자극반복패치테스트(human repeated insert patch test, HRIPT) 를 시행하였다. 연구의 기간은 2020 년 10 월 1 일부터 10 월 28 일까지

Table 1. Particulate matter (PM10) elements

\begin{tabular}{lc}
\hline Element & Certified value $(\mathrm{mg})$ \\
Arsenic & 7.1 \\
Cadmium & 0.9 \\
Lead & 113.0 \\
Nickel & 58.0 \\
\hline
\end{tabular}


총 4 주간 진행하였다.

피부자극반복패치테스트(HRIPT)의 검사 부위는 척추 기립 근을 축으로 양쪽 견갑골 사이로 정하였다. 검사 부위를 $70 \%$ 에 탄올로 닦은 후 각 시료들을 $25 \mu \mathrm{L}$ 씩 IQ ultra patch test units (Chemotechnique diagnostics, Velinge, Sweden)에 적하하여 고 정하였다. $48 \mathrm{~h}$ 동안 밀폐시킨 후 첩포를 제거하고 $1 \mathrm{~h}$ 후 피부 반 응을 확인하였다(Kim et al., 2019). 제조한 시료에 대한 안전성 확 보를 위해 첩포검사를 반복적으로 시행하여 극단적 환경을 부여하 였으며, 첩포검사 기간은 일주일에 1 회씩 총 4 주 동안 진행하였다. 결과 판독은 국제 접촉 피부염 연구위원회(International Contact Dermatitis Research Group; ICDRG)의 판정 기준(Table 3)에 따라 홍반 발생 여부 및 정도를 육안으로 관찰하였다.

\section{Animal experiment}

6 주령의 SKH-1 마우스 암컷(Orient Bio, Korea) 16 마리를 구입 하였다. Hairless 마우스 16마리를 일정한 온도 및 습도의 사육사에 서 7일간 적응시킨 후 실험에 사용하였다. 마우스는 대조군을 포함 하여 무작위로 4 개의 군(각각 $\mathrm{N}=4$ )으로 할당하였다. 실험동물의 사 육조건은 온도 $22 \pm 2{ }^{\circ} \mathrm{C}$, 습도는 $50 \pm 10 \%$, 조명 $12 \mathrm{~h}$ 명암으로 유지 해 주었다. 동물실험은 원광학교 동물실험윤리위원회(Institutional Animal Care and Use Committee, IACUC)의 사전심의(승인번호: WKU20-85)를 거쳐 실행하였다.

Control 군을 제외한 세 개 군의 hairless 마우스 등 피부 $1 \mathrm{~cm}^{2}$ 부 위에 PM10을 $10 \mu \mathrm{L}$ 씩 매일 1회 1주 동안 도포하였다. PM10을 일
주일간 도포한 후, 항오염 화장품을 처치하는 두 개 군의 hairless 마 우스 등 피부(PM10 도포 동일 부위)에 각각의 $3 \% \mathrm{PT}-7$ gel과 5\% PT-7 gel을 $100 \mu \mathrm{L}$ 씩 매일 1회 4주 동안 처치하였다.

\section{Immunohistochemistry (IHC)}

사이토카인의 발현 여부를 확인하기 위해 마우스의 등 피부를 채 취하여 immunohistochemistry를 실시하였다. 마우스 등 피부 조 직을 $4 \%$ para-formaldehyde를 이용하여 $4^{\circ} \mathrm{C}$ 에서 $24 \mathrm{~h}$ 동안 고정 한 후에 1차 항체 $\mathrm{L}-1 \beta$ (Abcam, USA), IL-6 (Abcam)를 상온에서 $2 \mathrm{~h}$ 동안 반응시켰다. 2 차 항체에 상온에서 $1 \mathrm{~h}$ 반응시킨 후 $\mathrm{PBS}$ 에 3 회 세척하고 Vector Elite ABC kit (Vector Laboratories, USA)을 이용하여 $1 \mathrm{~h}$ 동안 실온에서 반응시켰다. $3,3^{\prime}$-diaminobenzidine tetrahydrochloride (DAB)을 사용하여 발색시킨 후 유리 슬라이 드에 옮겨 염색이 끝난 조직 표본 슬라이드를 광학현미경(Nikon, Japan)을 사용하여 400 배율로 촬영하였다. 영상 결과의 판독은 피 부과 전문의 3 인이 5 단계로 구분하여 판독하였다. 판독기준은 $\mathrm{Kim}$ et al. (1998)의 연구를 참고하여 염색 강도와 상대적인 염색정도 (relative abundance)에 기초하여 정하였다(Table 4). Control을 0 등 급(negative)으로 기준하여, 염색 강도 5-25\%를 1등급(week), 26$50 \%$ 는 2 등급(mild), $51-75 \%$ 는 3 등급(moderate), $76-100 \%$ 는 4 등 급(strong)으로 판독하였다.

\section{Western blot}

채취한 마우스의 등 피부를 액화 질소를 사용하여 미세분말까

Table 2. Formulation of antipollution gels

(Unit: g)

\begin{tabular}{llcc}
\hline Element & \multicolumn{1}{c}{ Ingredients } & $3 \%$ PT-7 gel & $5 \%$ PT-7 gel \\
A & D.W & 89.47 & 87.47 \\
& Hydroxyethylcellulose & 1.30 & 1.30 \\
& Glycerin & 3.00 & 3.00 \\
B & Butylene glycol & 3.00 & 3.00 \\
& Disodium EDTA & 0.03 & 0.03 \\
C & 1-2 hexanediol & 0.20 & 0.20 \\
& Palmitoyl tetrapeptide-7 & 3.00 & 5.00 \\
\hline
\end{tabular}

Table 3. Grading criteria of skin reactions by ICDRG guideline

\begin{tabular}{ccl}
\hline Positive/negative & Score & \multicolumn{1}{c}{ Criteria } \\
- & 0 & No irritant reaction (Discrete patchy erythema without infiltration) \\
-+ & 0.5 & Doubtful reaction (Faint macular, no infiltration, homogenous erythema) \\
+ & 1 & Week positive reaction (Erythema, induration, papules) \\
++ & 2 & Strong positive reaction (Erythema, induration, papules, discrete vesicles) \\
+++ & 3 & Extreme Positive reaction (coalescing vesicles, bullous or ulcerative reaction) \\
\hline
\end{tabular}

ICDRG, International Contact Dermatitis Research Group. 
지 균질화 한 후 lysis buffer [20 mM Tris- $\mathrm{HCl}(\mathrm{pH}$ 7.5), 150 $\mathrm{mM} \mathrm{NaCl}, 1 \mathrm{mM}$ Na2EDTA 1 mM EGTA, 1\% NP-40, 1\% sodium deoxycholate, $2.5 \mathrm{mM}$ sodium pyrophosphate, $1 \mathrm{mM}$ $\beta$-glycerophosphate, $1 \mathrm{mM} \mathrm{Na} \mathrm{VO}_{4}, 1 \mu \mathrm{g} / \mathrm{mL}$ leupeptin]에 혼합 하여 용해하였다. 이를 얼음에 $30 \mathrm{mins}$ 둔 후 $12,000 \mathrm{rpm}, 4^{\circ} \mathrm{C}$ 에 서 원심분리하여 상층액을 취한 후 실험에 사용하였다. 수확된 단백 질은 bovine serum albumin (BSA; Sigma-Aldrich)의 표준 곡선을 통해 단백질량을 보정하여 western blot 시료로 사용하였다. Sample 을 $12 \% \mathrm{SDS}-\mathrm{PAGE}$ 를 이용해 전기영동하고 이를 membrane으 로 이전시킨 후, $4 \%$ skim milk에서 방치하였다. 단백질이 이전된 membrane을 $\beta$-actin (1:5,000, Bioworld, USA), IL-1ß (1:1,000, Abcam), $\mathrm{IL}-6$ (1:1,000, Abcam)에 대한 1차 항체를 $4^{\circ} \mathrm{C}$ 에서 24 $\mathrm{h}$ 동안 반응시킨 후 TBST로 세척하였다. 이어 2 차 항체 $(\alpha-r a b b i t$, $1: 1,000, \mathrm{Abcam})$ 를 $1 \mathrm{~h}$ 동안 반응시킨 후 TBST로 세척하였다. 이 후 Membrane에 ECL kit (Thermo fisher scientific, USA)를 이용 하여 필름에 옮겨 측정하였다.

\section{Statistical analysis}

자료 분석은 모두 유의수준 $5 \%$ 에서 검증하였으며, 통계처리는 SPSS for windows version 24.0 program (IBM, USA)을 사용하였 다. 데이터의 기술통계는 평균과 표준편차, 변화 값을 구하였다. 결 과의 비교 분석을 위해 paired $t$-test를 실시하였다.

\section{Results \& Discussion}

\section{Result of HRIPT}

PT-7 gel의 안전성 평가를 위해 피부자극 반복 패치테스트를 실 시한 결과는 Table 5 와 같다. 연구 지원자 30 명 전원이 4 주간의 패 치테스트에서 모두 음성(-) 반응이 나타났고 이는 3\% PT-7 gel과

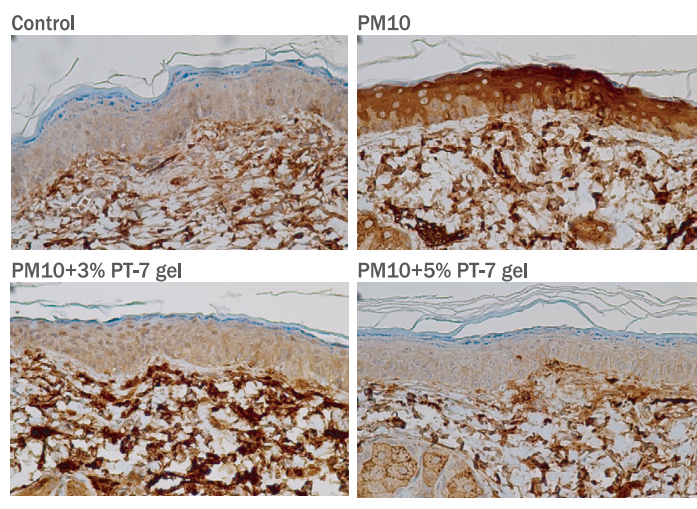

Figure 2. Immunohistochemical staining of the IL-1ß expression in hairless mouse skin $(\times 400)$.

CTR, control; PM, particulate matter; PT-7, palmitoyl tetrapeptide-7; PM10+3\% PT-7 gel, application of 3\% PT-7 gel after PM10 treatment; PM10+5\% PT-7 gel, application of 5\% PT-7 gel after PM10 treatment.

$5 \% \mathrm{PT}-7$ gel을 인체에 반복하여 사용하였을 때 피부 알레르기 반응 이 나타나지 않음을 확인한 결과이다. Johnson et al. (2018)의 연구 에서 PT-7 $500 \mathrm{ppm}(0.0005 \%)$ 과 다른 유효 성분을 함유한 화장품 을 제조하여 18-79세의 피험자 52명을 대상으로 주 3 회 $24 \mathrm{~h}$ 패치 테스트를 실시한 결과 피부자극과 알레르기 반응이 없음을 보고하였 다. 두 연구 결과를 비교하였을 때 PT-7에 대한 피부적용 안전성이 확보된 결과를 도출하였으며 특히 이 연구에서는 PT-7의 원료 함량 이 $5 \%$ 로 높게 적용되었으나 피부부작용이 나타나지 않아 PT-7의 함량이 $5 \%$ 까지 높게 사용할 경우의 피부 적용 안전성을 확인하였다.

\section{Result of $\mathrm{IL}-1 \beta$ expression}

$\mathrm{PM} 10$ 을 일주일간 처치 후 $3 \% \mathrm{PT}-7$ gell과 5\% PT-7 gel을 각각 4 주간 도포하여 항염증 효능을 평가하였다. $\mathrm{IHC}$ 영상 Figure 2에서 control을 기준으로 염색강도를 판독한 결과, PM10 처치군의 score

Table 4. Immunohistochemical staining grading system

\begin{tabular}{llcc}
\hline Grade & Staining intensity & Percentage of positive stained & Score \\
0 & Negative & 0 & 0 \\
1 & Week & $5-25$ & 1 \\
2 & Mild & $26-50$ & 2 \\
3 & Moderate & $51-75$ & 3 \\
4 & Strong & $76-100$ & 4 \\
\hline
\end{tabular}

Table 5. The results of the patch test for 4 weeks

$(\mathrm{N}=\mathbf{3 0})$

\begin{tabular}{|c|c|c|c|c|c|}
\hline Grade & Reaction & 1 week & 2 weeks & 3 weeks & 4 weeks \\
\hline \multirow{2}{*}{ 3\% PT-7 gel } & Positive & 0 & 0 & 0 & 0 \\
\hline & Negative & 30 & 30 & 30 & 30 \\
\hline \multirow{2}{*}{ 5\% PT-7 gel } & Positive & 0 & 0 & 0 & 0 \\
\hline & Negative & 30 & 30 & 30 & 30 \\
\hline
\end{tabular}


A

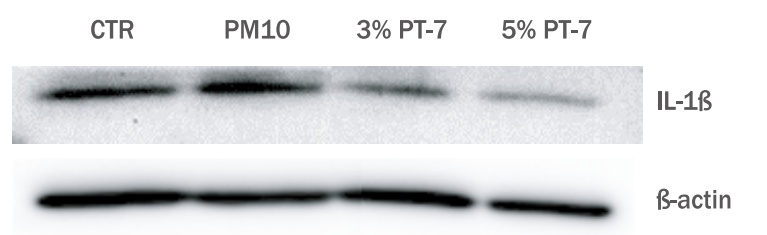

B

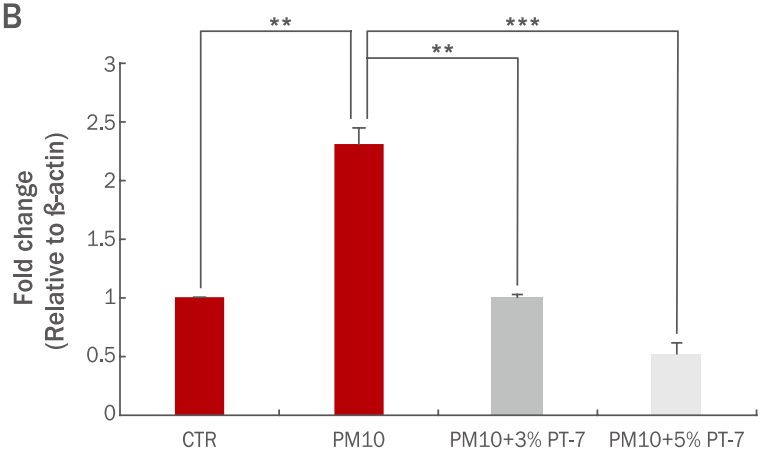

Figure 3. The effect of antipollution cosmetic containing PT-7 on PM10-induced IL-1ß expression.

Data are presented as the mean $\pm S D$ of the three independent experiments performed in triplicate. Data were analyzed using paired t-test. Significance indicated by ${ }^{*},{ }^{* *}$, and ${ }^{* * *}$ indicates $p<0.05, p<0.01$, and $p<0.001$, respectively. CTR, control; PM, particulate matter; PT-7, palmitoyl tetrapeptide-7; PM10+3\% PT-7 gel, application of 3\% PT-7 gel after PM10 treatment; PM10+5\% PT-7 gel, application of 5\% PT-7 gel after PM10 treatment; IL-1ß, Interleukin 1 beta.

평균은 $4.00 \pm 0.00$ 으로 4 등급(strong)으로 평가하였다. PM10처치 후 $3 \% \mathrm{PT}-7$ gel을 도포한 군의 $\mathrm{IL}-1 \beta$ 의 발현은 score 평균이 1.33 \pm 0.57 로 grade 1 (week)에 해당하였으며, $5 \%$ PT- 7 gel을 도포 한 군은 염색강도에 대한 score 평균이 $0.66 \pm 0.57$ 로 역시 grade 1 (week)으로 판독하였다.

미세먼지에 의해 유발된 $\mathrm{IL}-1 \beta$ 의 발현을 $\mathrm{IHC}$ 에 의해 분석한 선 행연구를 살펴보면, 인체피부각질형성세포에 미세먼지 처치 후 $\mathrm{IHC}$ 를 실시하였을 때 $\mathrm{IL}-1 \beta$ 의 발현에 큰 영향을 미치지 않았다는 보고 가 있었다(Lee et al., 2016). 이 연구에서는 hairless 마우스의 등 피 부에 PM10을 처치 후 $\mathrm{IHC}$ 를 실시하고 판독한 결과, $\mathrm{LL}-1 \beta$ 의 발현 이 증가하였다. 이러한 결과의 차이는 in vitro와 in vivo 실험 환경 에 따른 차이인 것으로 사료된다.

$\mathrm{IL}-1 \beta$ 에 대한 western blot 결과는 Figure 3 과 같다. Hairless 마 우스 등 피부에 일주일간 PM10을 처치하였을 때 $\mathrm{IL}-1 \beta$ 의 발현이 증가하였다 ${ }^{* *} p\langle 0.01)$. PM10을 1 주일간 처치 후 $3 \% \mathrm{PT}-7$ gel을 4 주간 도포한 결과, $\mathrm{IL}-1 \beta$ 의 발현이 감소하였으며 통계적으로 유의 한 차이를 보였다 $\left.{ }^{* *} p<0.01\right)$. 특히, $5 \% \mathrm{PT}-7$ gel을 4 주간 도포한 결 과에서는 PM10 처치 후 $\mathrm{IL}-1 \beta$ 의 발현을 억제시켰으며 이는 통계적 으로 유의한 차이를 보였다 $\left.{ }^{* * *} p<0.001\right)$.

미세먼지에 의해 유발된 IL-1ß의 발현을 western blot에 의해 분 석한 선행연구에서 각질형성세포에 PM10을 처리하였을 때 $\mathrm{IL}-1 \beta$ 의 발현이 증가하였으며(Choi et al., 2018), 이러한 결과는 본 연 구자의 결과와 유사하다. 미세먼지는 피부에서 염증성 사이토카인 의 발현을 증가시키며, 그 중에서도 $\mathrm{IL}-1 \beta$ 는 pro-inflammatory cytokine으로 염증성 질병의 매개체로 작용한다. 손상된 피부장벽 내로 미세먼지가 침투하면 $\mathbb{L}-1 \beta$ 의 발현이 증가하면서 피부 노화, 건선, 아토피성 피부염 등과 같은 피부질환을 유발한다. 이 연구의 결과 PT-7을 사용하여 제조한 gel은 PM10 노출된 hairless 마우스

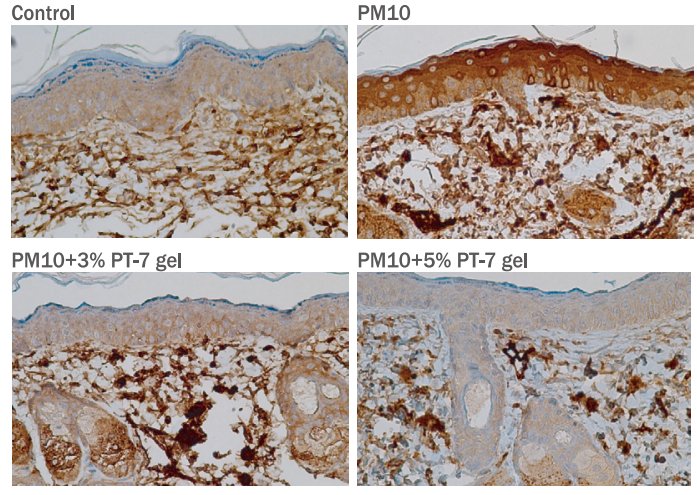

Figure 4. Immunohistochemical staining of IL-6 expression in hairless mouse skin $(\times 400)$.

CTR, control; PM, particulate matter; PT-7, palmitoyl tetrapeptide-7; PM10+3\% PT-7 gel, application of 3\% PT-7 gel after PM10 treatment; PM10+5\% PT-7 gel, application of 5\% PT-7 gel after PM10 treatment; IL-6, interleukin-6.

의 피부에서 $\mathrm{LL}-1 \beta$ 의 발현을 감소시키는 것을 확인하였다.

\section{Result of $\mathrm{LL}-6$ expression}

$\mathrm{IL}-6$ 항체를 이용하여 $\mathrm{IHC}$ 를 실시한 결과는 Figure 4 와 같다. Control (negative)을 기준으로 염색강도를 판독한 결과, PM10 처치 군은 $3.33 \pm 0.57$ 로 3 등급(moderate)으로 나타났다. PM10 처치 후 $3 \% \mathrm{PT}-7$ gel을 도포한 군은 score 평균이 $2.00 \pm 0.00$ 으로 2 등급 (mild)에 해당하였으며, 특히 PM10 처치 후 $5 \%$ PT-7 gel을 도포한 군은 score 평균이 $0.33 \pm 0.57$ 로 control과 같은 0 등급(negative)으 로 판독하였다. 미세먼지 처치 후 $\mathrm{IL}-6$ 의 발현을 $\mathrm{IHC}$ 로 분석을 실시 한 선행연구에서 각질형성세포에 미세먼지를 처치하였을 때 $\mathbb{L}-6$ 의 발현이 증가하였다는 보고가 있었으며(Lee et al., 2016), 이는 이 연 
A

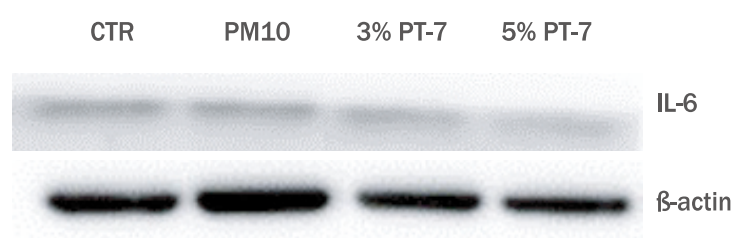

B

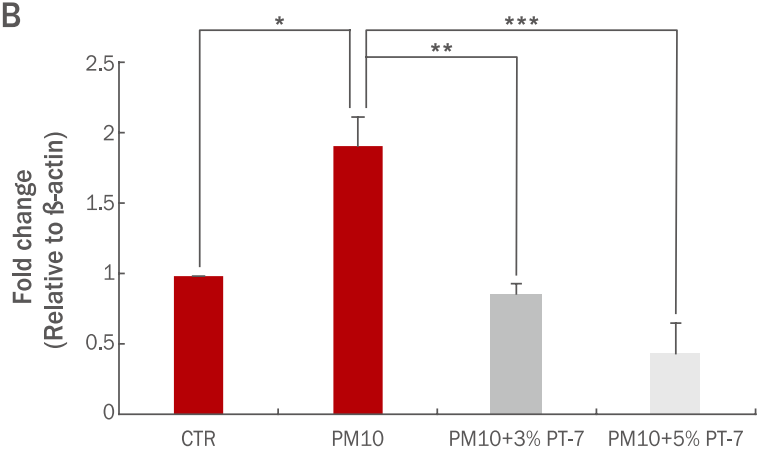

Figure 5. The effect of antipollution cosmetic containing PT-7 on PM10-induced IL-6 expression.

Data are presented as the mean $\pm S D$ of the three independent experiments performed in triplicate. Data were analyzed using paired t-test. Significance indicated by ${ }^{*},{ }^{* *}$, and ${ }^{* * *}$ indicates $p<0.05, p<0.01$, and $p 0.001$, respectively. CTR, control; PM, particulate matter; PT-7, palmitoyl tetrapeptide-7; PM10+3\% PT-7 gel, application of 3\% PT-7 gel after PM10 treatment; PM10+5\% PT-7 gel, application of 5\% PT-7 gel after PM10 treatment; IL-6, interleukin-6.

구와 유사한 결과이다.

Hairless 마우스 등 피부에 PM10을 도포하고 IL-6의 발현 정도 를 western blot을 실시한 결과는 Figure 5 와 같다. PM10에 의해 $\mathrm{IL}-6$ 의 발현이 증가 $\left.{ }^{*} p<0.05\right)$ 되었으며, PM10 처치 후 4 주간 $3 \%$ $\mathrm{PT}-7$ gel을 도포한 결과, PM10 처치 군에 비해 $\mathrm{IL}-6$ 의 발현이 감 소하였으며, 통계적으로 유의한 차이를 보였다( $\left.{ }^{* *} p<0.01\right) .5 \% \mathrm{PT}-7$ gel 경우에도 $\mathrm{IL}-6$ 의 발현이 감소하였으며 통계적으로 유의한 차이 를 보였다 $\left(^{* * *} p<0.001\right)$.

IL-6는 pro-inflammatory cytokine의 일종으로 피부를 비롯 한 다수의 세포에서 분비된다. 지금까지 알려진 기능은 면역계, 대 사와 신경계를 조절하고 여러 가지 자가면역질환을 유발하는 것이 다. 아토피피부염, 건선 환자의 피부에서 $\mathrm{IL}-6$ 발현이 증가되어 있 는 점 등은 염증반응 유발에 $\mathrm{L}-6$ 가 관여하고 있다는 증거이다. 이 처럼 $\mathrm{IL}-6$ 는 피부 면역과 염증 유발에 중요한 역할을 수행하고 있기 때문에 미세먼지와 같은 외부 유해물질이 피부에 침투했을 때 유사 한 기능을 수행할 것이라고 쉽게 예측할 수 있다. 따라서 이 연구에 서는 미세먼지에 의해 발생하는 IL-6 발현 감소에 효능이 예측되는 PT-7을 원료로 gel을 제조하여 IL-6에 대한 항염증 효능을 평가하 였다.

$\mathrm{IL}-6$ 의 발현 억제 효능에 관한 선행연구에서 PT-7이 UVB에 노출된 인체유래세포의 IL-6 발현을 감소시킨다는 보고가 있었 으며(Johnson \& Heldreth, 2012), 이 연구에서도 PM10에 노출 된 hairless 마우스에 PT-7을 사용하여 gel을 만든 후 도포한 결과 $\mathrm{IL}-6$ 의 발현이 억제되는 것을 확인하였다. 따라서 $\mathrm{PT}-7$ 은 UVB뿐 만 아니라 PM10 노출 후 유도된 IL-6의 발현을 감소시키는 것을 확 인하였다.

최근 시판되고 있는 펩타이드 원료 화장품은 비교적 분자량이 작
아 피부 각질층을 쉽게 통과할 수 있는 장점이 있다. 작은 분자량 에도 불구하고 여전히 피부 각질층을 투과하는 것은 어려운 일이 기 때문에 펩타이드 분자에 친유성의 palmitoyl 기를 결합한 변형 된 펩타이드를 화장품 원료로 사용하여 피부 투과성을 높이고 있 다. Carnosine과 palmitoyl-carnosine의 피부 투과 비교 실험에 서 palmitoyl-carnosine이 약 25배 정도 피부 투과성이 높은 것으 로 밝혀졌다(Lintner et al., 2000). 이런 결과를 토대로 본 연구에서 palmitoyl 기가 결합된 합성 펩타이드를 실험에 사용하였다. In vivo 실험 결과 PT-7이 항염증 효과가 있음을 확인하였고 PT-7 gel이 마우스 피부에 충분하게 흡수되어 생물학적 작용을 일으켰을 것으로 판단하였다.

\section{Conclusion}

이 연구에서는 항염증 효능이 예측되는 PT-7을 이용하여 항오염 화장품을 제조하였다. 제조된 시료의 안전성을 평가하였으며, PM10 에 의한 피부 염증 발현 억제 효능을 평가하였다.

피부자극반복패치테스트를 실시한 결과 3\% PT-7 gel과 5\% PT-7 gel 모두 연구지원자 30명 전원에서 음성(-) 반응을 보여 피 부 자극에 대한 안전성을 확보하였다. 항염증 효능평가를 위해 $\mathrm{IHC}$ 를 실시하고 피부과 전문의 3 인이 판독을 실시한 결과, $3 \% \mathrm{PT}-7$ gel, $5 \%$ PT-7 gel 모두 PM10 노출에 의해 발생한 IL-1ß와 IL-6의 발현이 감소하였다. Western blot 결과 3\% PT-7 gel, 5\% PT-7 gel 모두 PM10 노출에 의해 발생한 $\mathrm{IL}-1 \beta$ 와 $\mathrm{IL}-6$ 의 발현이 감소하였 으며, $5 \% \mathrm{PT}-7$ gel의 경우 $\mathrm{IL}-1 \beta$ 와 $\mathrm{IL}-6$ 의 발현이 현저하게 감소 하였다. 
결론적으로 $3 \% \mathrm{PT}-7 \mathrm{gel}, 5 \% \mathrm{PT}-7$ gel 모두 PM10 노출에 의해 증가된 염증성 사이토카인 $\mathrm{IL}-1 \beta$ 와 $\mathrm{IL}-6$ 의 발현을 감소시키는 것 을 확인하였다. 특히 PT-7을 5\%로 제조한 gel에서 $\mathrm{IL}-1 \beta$ 와 $\mathrm{IL}-6$ 의 발현 억제가 우수하였다.

현재 출시되고 있는 항오염 화장품은 미세먼지 차단에 집중되어 있으며 그 효능이 입증되지 않은 사례도 보고되고 있다. 그러나 이 연구에서는 미세먼지로부터 피부손상을 줄이고 회복시킬 수 있는 항 오염 화장품의 소재로 PT-7을 선정하여 gel을 제조하고 in vivo에 적용하여 항염증 효능을 제시하였다. 이 연구의 결과를 통해 PT-7 을 사용하여 제조한 항오염 화장품의 안정성 및 안전성이 검증되었 으며, PT-7의 항오염 화장품 소재로서 활용가능성을 확인하였다.

\section{Acknowledgements}

이 논문은 2018년 대한민국 교육부와 한국연구재단의 지원을 받아 수행된 연구임(NRF-2018S1A5A2A01030026).

\section{Author's contribution}

MKK and MJK contributed equally to this work. MKK and MJK designed all experimental investigations. JWK performed experiments and wrote manuscript. JHK oversaw the project.

\section{Author details}

Min-Kyeong Kim (Gradutae student). Department of Beauty Design, Graduate School of Wonkwang University, 460 Iksan-daera, Iksan-si, Jeallabuk-do 54538, Koera; Min-Jung Kim (Visiting Professor). Division of Beauty Design, Wonkwang University 460, Iksan-daera, Iksansi, Jeallabuk-do 54538, Korea; Ju-Weon Kim (Gradutae student). Department of Beauty Design, Graduate School of Wonkwang University, 460 Iksan-daera, Iksan-si, Jeallabuk-do 54538, Koera; Jeong-hee Kim (Professor), Division of Beauty Design, Wonkwang University 460, Iksan-daera, Iksan-si, Jeallabuk-do 54538, Korea.

\section{References}

An EJ, Kim JH. The survival rate of cultured epithelial keratinocyte cell and dermal fibroblast cell treated with particulate matter (PM10). Journal of The Korean Society of Cosmetology, 25: 822-826, 2019.

Ahn KM. The role of air pollutants in atopic dermatitis. The Journal of Allergy and Clinical Immunology, 134: 993-
999, 2014.

Araviiskaia E, Berardesca E, Bieber T, Gontijo G, Sanchez Viera M, Marrot L, Chuberre B, Dreno B. The impact of airborne pollution on skin. Journal of the European Academy of Dermatology and Venereology, 33: 14961505, 2019.

Choi MA, Seok JK, Lee JW, Lee SY, Kim YM, Boo YC. Effects of resveratol and resveratryl triacetate on the inflammatory responses of human epidermal keratinocytes exposed to airborne particulate matter PM10. Journal of the Society of Cosmetic Scientists of Korea, 44: 249-258, 2018.

Drakaki E, Dessinioti clio, Antoniou CV. Air pollution and skin. Environmental Science, 2: 1-6, 2014.

Fermández JR, Webb C, Rouzard K, Voronkov M, Huber KL, Stock JB, Healy J, Tamura M, Stock M, Armbrister W, Gordon JS, Pérez E. SIG-1273 protects skin against urban air pollution and when formulated in AgelQ ${ }^{\mathrm{TM}}$ night cream anti-aging benefits clinically demonstrated. Journal of Cosmetic Dermatology, 18: 1366-1371, 2018.

Fields K, Falla TJ, Rodan K, Bush L. Bioactive peptides: signaling the future. Journal of the Cosmetic Dermatology, 8: 8-13, 2008.

Huss-Marp J, Eberlein-König B, Breuer K, Mair S, Ansel A, Darsow U, Krämer U, Mayer E, Ring J, Behrendt H. Influence of short-term exposure to airborne Der $\mathrm{p} 1$ and volatile organic compounds on skin barrier function and dermal blood flow in patients with atopic eczema and healthy individuals. Clinical and Experimental Allergy, 36: 338-45, 2006.

Johnson W, Bergeld WF, Belsito DV, Hill RA, Klaassen CD, Liebler DC, Marks JG, Shank RC, Slaga TJ, Snyder PW, Gill LJ, Heldreth B. Safety assessment of tripeptide-1, hexapeptide-12, their metal salts and fatty acyl derivatives, and palmitolyl tetrapeptide- 7 as used in cosmetics. International Journal of Toxicology, 37: 90102, 2018.

Johnson W, Heldreth B. Safety assessment of palmitoyl oligopeptides as used in cosmetics. Cosmetic Ingredient Review, Washington, pp1-20, 2012.

Juliano C, Magrini GA. Cosmetic functional ingredients from botanical sources for anti-pollution skincare products. Cosmetics, 5: 1-18, 2018.

Kim GY, Lee SJ, Jeon MJ, Kim BM, Kim GT, Kang SM, Lee KY, Shin EJ, Kim SY, Kim YM. Anti-wrinkle and skin 
turnover improvement effects of niacinamide-dipeptide convergence. Asian Journal of Beauty and Cosmetology, 16: 243-254, 2018.

Kim JH, Kim EH, Oh I, Jung K, Han Y, Cheong HK, Ahn $K$. Symptoms of atopic dermatitis are influenced by outdoor air pollution. The Journal of Allergy and Clinical Immunology, 132: 495-8, 2013.

Kim JN, Kim WI, Shim SI, Kang CS, Lee KY, Kim YS. Expression of the $\mathrm{nm} 23$ and e-cadherin proteins in breast carcinoma. Journal of Pathology and Translational Medicine, 32: 29-34, 1998.

Kim KE, Cho D, Park HJ. Air pollution and skin diseases: adverse effects of airborne particulate matter on various skin diseases. Life Sciences, 152: 126-134, 2016.

Kim MJ, Park K, Kim JH. Safety assessment of natural color foundation for atopy. Asian Journal of Beauty and Cosmetology, 17: 169-177, 2019.

Krutmann J, Liu W, Li L, Pan X, Crawford M, Sore G, Seite S. Pollution and skin: from epidemiological and mechanistic studies to clinical implications. Journal of Dermatological Science, 76: 163-168, 2014.

Lee CW, Lin ZC, Hu SCS, Chiang YC, Hsu LF, Lin YC, Lee IT, Tsai MH, Fang JY. Urban particulate matter downregulates filaggrin via COX2 expression/PGE2 production leading to skin barrier dysfunction. Scientific Reports, 6: 1-16, 2016.

Lee JS. Consumer perception and selection attributes of anti-pollution cosmetics. Asian Journal of Beauty and Cosmetology, 16: 465-476, 2018.

Lintner K, Peschard O. Biologically active peptides: from a laboratory bench curiosity to a functional skin care product. International Journal of Cosmetic Science, 22: 207-218, 2000.

Mondon P, Hillion M, Peschard O, Andre N, Marchand T, Doridot E, Feuilloley MGJ, Pionneau C, Chardonnet S. Evaluation of dermal extracellular matrix and epidermaldermaljunction modifications using matrix-assisted laser desorption/ionization mass spectrometric imaging, in vivo reflectance confocalmicroscopy, echography, and histology: effect of age and peptide applications. Journal of Cosmetic Dermatology, 14: 152-160, 2015.

Park SY, Byun EJ, Lee DJ, Kim SJ, Kim HS. Air pollution, autophagy, and skin aging: impact of particulate matter (PM10) on human dermal fibroblasts. International Journal of Molecular Sciences, 19: 1-15, 2018.

Piao MJ, Ahn MJ, Kang KA, Ryu YS, Hyun YJ, Shilnikova K, Zhen AX, Jeong JW, Choi YH, Kang HK, Koh YS, Hyun JW. Particulate matter 2.5 damages skin cells by inducing oxidative stress, subcellular organelle dysfunction, and apoptosis. Archives of Toxicology, 92: 2077-2091, 2018.

Ryu YS, Kang AK, Piap MJ, Ahn MH, Yi JM, Hyun YM, Kim SH, Ko MK, Park CO, Hyun JW. Particulate matter induces inflammatory cytokine production via activation of MNFKB by TLR5-NOX4-ROS signaling in human skin keratinocyte and mouse skin. Redox Biology, 21: 101080, 2019.

Vierkötter A, Schikowski T, Ranft U, Sugiri D, Matsui M, Krämer U, Krutmann J. Airborne particle exposure and extrinsic skin aging. The Journal of Investigative Dermatology, 130: 2719-2726, 2010. 


\section{국문초록}

\section{Palmitoyl Teterapeptide-7 Gel0 이 PM10에 의해 유발된 염증 반응 제어 효과}

김민경 ${ }^{1}$, 김민정 ${ }^{2}$, 김주원 ${ }^{1}$, 김정희 ${ }^{2 *}$

${ }^{1}$ 원광대학교대학원 뷰티디자인학과, 전라북도 익산시, 한국

${ }^{2}$ 원광대학교 자연과학대학 뷰티디자인학부, 전라북도 익산시, 한국

목적: 최근 환경오염이 미치는 인체 유해성에 대한 인식이 높아지면서 미세먼지 차단뿐 아니라 미세먼지로 인한 피부 손상을 줄이 고 회복시킬 수 있는 제품 개발이 요구되고 있다. 따라서 이 연구에서는 palmitoyl tetrapeptide-7 (PT-7)을 이용하여 화장품을 제 조하고 안정성 및 안전성, 항오염 효능을 평가하였다. 방법: 항오염 화장품은 항염증 효능이 예상되는 PT-7을 사용하여 $3 \% \mathrm{PT}-7$ gel, $5 \% \mathrm{PT}-7$ gel을 제조하였다. 화장품 안전성 측면에서, 20-50대의 피부질환 및 피부 과민 반응이 없는 성인을 대상으로 인체 적 용에 대한 피부자극반복패치테스트(human repeat insult patch test)를 실시하였다. 제조한 항오염 화장품의 효능을 평가를 위해 hairless 마우스 등 피부에 PM10을 일주일간 노출시킨 후 3\% PT-7 gel, 5\% PT-7 gel을 4주 간 도포하였다. 마우스 등 피부를 채 취하여 PM10에 의해 발현된 $\mathbb{L}-1 \beta, \mathrm{L}-6$ 의 억제 정도를 immunohistochemistry ( $\mathrm{HC}$ )와 western blot을 이용하여 확인하였다. 결 과: 인체적용에 대한 안전성 평가 결과, $3 \% \mathrm{PT}-7$ gel과 $5 \% \mathrm{PT}-7$ gel 모두 음성 (-) 반응이 나타나 안전성을 확인하였다. 항염증 효 능평가를 위해 $\mathrm{HC}$ 의 영상을 판독한 결과 PM10 처치 후 $3 \% \mathrm{PT}-7$ gel과 $5 \% \mathrm{PT}-7$ gel 도포 군 모두 PM10 처치 군에 비해 $\mathrm{L}-1 \beta$, $\mathbb{L}-6$ 의 발현이 감소하였다. Western blot 결과, $3 \% \mathrm{PT}-7$ gel과 $5 \% \mathrm{PT}-7$ gel 도포 군 모두 PM10 노출에 의한 $\mathrm{L}-1 \beta, \mathrm{L}-6$ 의 발현 을 억제되었으며, 특히 $5 \% \mathrm{PT}-7 \mathrm{gel}$ 의 경우 $\mathbb{L}-1 \beta, \mathrm{L}-6$ 의 발현을 현저히 억제되어 통계적으로 유의한 차이를 보였다. 결론: 이상 의 결과를 종합하면 PT-7을 함유한 항오염 화장품은 PM10 노출에 의해 유발된 염증성 사이토카인 $\mathrm{L}-6, \mathbb{L}-1 \beta$ 의 발현을 감소시 키는 것을 확인하였다. 따라서 PT-7은 미세먼지로 인한 피부손상 예방 또는 개선을 위한 기능성 제품으로의 활용을 기대할 수 있 다.

핵심어: 항오염, 팔미토일 테트라펩타이드-7 (PT-7), 미세먼지 (PM10), 항염증, 화장품

이 논문은 2018년 대한민국 교육부와 한국연구재단의 지원을 받아 수행된 연구임(NRF-2018S1A5A2A01030026).

\section{참고문헌}

김가연, 이승제, 전미지, 김보민, 김근태, 강상문, 이기영, 신은진, 김상용, 김영민. 나이아신 펩타이드 융합체의 항주름 및 피부 턴오버 개선 효과. 아시안뷰티화장품학술지, 16: 243-254, 2018.

김민정, 박건, 김정희. 아토피용 천연 파운데이션의 안전성 평가. 아시안뷰티화장품학술지, 17: 169-177, 2019.

김진아, 김원일, 심상인, 강창석, 이교영, 김영신. 유방암종에서의 $\mathrm{nm} 23$ 및 $\mathrm{E}$-cadherin 단백질의 발현. 대한병리학회지,

32: 29-34, 1998.

안은주, 김정희. 미세먼지 PM10이 피부각질형성세포와 피부섬유아세포에 미치는 세포생존율 분석. 한국미용학회지, 25:

822-826, 2019.

이지선. 안티폴루션 화장품의 소비자인식 및 선택속성. 아시안뷰티화장품학술지, 16: 465-476, 2018.

최민아, 석진경, 이정원, 이신영, 김영미, 부용출. 대기 미립자 물질 PM10에 노출된 인간 표피 각질형성세포의 염증 반응

에 대한 레스베라트롤과 레스베라트릴 트라이아세테이트(RTA)의 영향. 대한화장품학회지, 44: 249-258, 2018. 


\section{中文摘要}

\section{棕桐酰四肽7凝胶对PM10引起的炎症反应的控制作用}

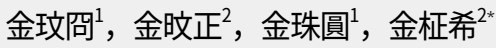

1圆光大学大学院美容设计学科, 全罗北道盆山市, 韩国

2圆光大学大学自然科学大学容设计学科, 全罗北道盆山市, 韩国

目的: 作为防止这种污染引起的皮肤损害的美容方法, 局部应用注入了功能性成分的护肤产品可以为这些问题提 供最佳的解决方案。这项研究的目的是评估PT-7凝胶的抗炎作用。方法: 本研究使用PT-7 (3\%PT-7凝胶, 5\% PT-7凝胶）制备了抗污染化妆品, 并进行了安全性测试。为了进行安全性评估, 进行了人类反复刺激贴布试验 （human repeat-insult patch test, HRIPT），以检测斑块区域是否出现红斑，并遵循ICDRG的标准。该小组 由30位成年人组成, 年龄在 20 至 50 岁之间。此外, 该研究还通过免疫组织化学和蛋白质印迹分析了PM10诱导 的无毛小鼠皮肤炎症。结果: 化妆品安全性测试的结果表明, 皮肤对含有PT-7的抗污染凝胶没有反应。免疫组织 化学表明, $3 \% \mathrm{PT}-7$ 和 $5 \% \mathrm{PT}-7$ 应用组与P10处理群相比, IL-1 3 和IL-6表达水平降低了。此外, 蛋白质印迹分析 表明, PM10处理后, 在 $3 \%$ PT-7和 $5 \%$ PM 10 PT-7应用组中IL-1 3 和IL-6的表达水平降低。特别地, 在用PM10治 疗后, 在用 $5 \% \mathrm{PT}-7$ 治疗的组中IL-1 $\beta$ 和IL-6的表达水平在统计学上显着降低。结论: 综上所述, 该研究提供了证 明PT-7凝胶具有安全性的证据。此外, 这项研究还发现PT-7凝胶可降低PM10暴露引起的IL-1ß和IL-6的表达水 平。鉴于这些结果，这项研究支持PT-7是一种很有前途的抗污染化妆品成分，具有巨大的商业潜力。

关键词: 抗污染，棕桐酰四肽7（PT-7），颗粒物（PM10），抗炎，化妆品 